\title{
Comparison of Doping Knowledge Levels of Two Different University Learning Students
}

\begin{abstract}
${ }^{2}$ A,Vahit DOĞAR, ${ }^{1}$ Metin BAYRAM, ${ }^{2}$ Kenan ŞEBIN, ${ }^{1}$ Gökhan BAYRAKTAR, ${ }^{1}$ Serkan T.AKA ${ }^{1}$ Ağrı İbrahim Çeçen University of Physical Education and Sports High School AĞRI/TÜRKIYE ${ }^{2}$ Atatürk University excavation education faculty physical education and sports department ERZURUM/TÜRKIYE
\end{abstract}

\section{ABSTRACT}

The aim of this study was to determine the doping knowledge levels of the students of Ağrı İbrahim Chechen University School of Physical Education and Sports and Atatürk University Faculty of Education Physical Education and Sports Teaching Department. Ağrı İbrahim Çeçen University 200 students studying at the School of Physical Education and Sports 334 students studying at the Department of Physical Education and Sports Teaching at Ataturk University Faculty of Education have been applied and a total of 534 questionnaires have been evaluated. The scope validity, comprehensibility and reliability of the questionnaire consisting of 32 questionnaires in order to determine the level of doping information was made by enthusiasm and cronbach alpha reliability coefficient in the 2006-2007 school year was determined as 0.92 . $(0.80<x<1.00)$, the data collection tool is highly reliable. Information obtained from the questionnaire The frequency and percentage values were taken in the SPSS 16.0 package program. The frequency and percentage distribution of the demographic characteristics of the students participating in the survey and the results of the chi-square test to determine the relationship between the independent variables and the opinions related to the use of doping.

Key Words: Doping,, Knowledge level, Ergogenic helpers

*Correspondence to Author: Metin BAYRAM

Ağrı İbrahim Çeçen University of Physical Education and Sports High School AĞRI/TÜRKIYE

How to cite this article:

A,Vahit DOĞAR, Metin BAYRAM, Kenan ŞEBIN, Gökhan BAYRAKTAR, Serkan T.AKA. Comparison of Doping Knowledge Levels of Two Different University Learning Students. American Journal of Educational Research and Reviews, 2017,2:7.

\section{eSciencePublisher}

eSciPub LLC, Houston, TX USA. Website: http://escipub.com/ 


\section{INTRODUCTION}

Doping can be defined as "The deliberate or unintentional use of subtances or methods banned by the International Olympic Committee (IOC) by the athletes".

Doping cases have been increasing considerably since 1950. During the 1950 Oslo Winter Olympics, lots of broken vaccine vials and injectors were found in speed skaters' chambers. Doping cases were officially filed in the 1952 Helsinki Summer and Oslo Winter Olympics, in the 1956 Melbourne Summer and Cortina d'Ampezzo Winter Olympics, in the 1960 Rome Summer and Squaw Valley Winter Olympics and in the 1972 Munich Summer Olympics (Açıkada and Ergen 1990). It was stated that doping was explicitly used in the 1960 Rome Summer Olympics. Also, the Federation of Sports Medicine in Holland reported the wide range of doping use in almost all cycling competitions in both professional and amateur fields (Akgün 1993).

In the 1964 Tokyo Summer Olympics, it was seen that athlete's muscle mass had extremely increased and World Records had been broken one after another. Immediately after the Olympics, IOC redefined doping, brought stricts rules and determined banned subtances' list (Kalyon 1994). The first official doping control started in the 1968 Mexico Olympics. However, it was inadequate both in terms of methods and organization. It was the 1972 Munich Olympics that saw the first serious and official adequate doping control. In the same year, leaflets about doping were published in every language, banned subtances list was reviewed, updated and sent to National Olympic Committee. In the 1976 Montreal Olympics, the anti-doping organization was extended and the analysis methods helped determine the limits of blood value levels, so anabolic steroids were included in the banned drugs list. A much bigger antidoping organization was held in the 1980 Moscow Olympics. Sports branches which will be controlled, the list of drugs that have no doping and limited use and analysis methods were dealt in detail (Temizer 1994). 7 athletes out of 19 were disqualified in the 1983 PanAmerican Games after their urine samples tested positive for a banned substance. And 7 weightlifters competing for 5 different countries in the same competition were identified with doping use.

Some of the athletes from the United States national cycling team accepted using blood doping during the 1984 Los Angeles Summer Olympics (Kurdak 1996). Although we have seen much of the use of performance-enhancing drug or methods in recent years, their use goes far back to ancient Greek civilizations. Athletes of that time were using substances such as fungus, ginseng and morphine to icrease their strength. Some athletes chose not to use such subtances or methods and conformed to the sports ethics; however, some tried to surpass others by taking advantage of the technological and medical world.

Oxygen circulation in the body can be artificially increased with the help of specific high-altitude training techniques and high-technology drugs. An athlete not only gets faster but also feels less tired with the help of these drugs and techniques. Although the use of blood doping is banned in most sports branches, the abundance of the techniques and the detailed plannings make it hard to identify the use of such doping. For instance, the reason behind high level hormones in an athlete's blood could be his/her own physical chemisty or it could be given artificially to the athlete. It is usually difficult to identify such anomalies. Also, would it be OK to approve techniques that increase oxygen levels in blood by natural (drug-free) means? Are such methods suitable for sports ethics? Anwers to these kinds of questions still remain unclear, but many athletes applied to such methods in their sports lives http://sIn.fi.edu/01.14.2017. The term "doping" is commonly used to refer to substances or methods that athletes use in competitions to gain an advantage over others. The artifical increment of oxygen level in one's blood is done by increasing an individual's 
hemoglobin concentration above normal level and this doping method is called blood doping. The blood doping is generally performed either by blood transfusion or blood transfer to a person's veins. Both methods increase hemoglobin level. An increment in hemoglobin level boosts oxygen circulation because extra hemoglobin molecules perform the circulation of extra oxygen in the body. As a result, athlete's stamina and performance increase. http://www.wada-ama.org/01.14.2017. Doping was first officially defined in 1963. So doping means During the competition or while getting prepared for the competition athletes or players increase their performances artificially. Doping's definition goes far back to ancient times. First doping cases can be traced back to $3^{\text {rd }}$ century B.C. olympic games (Stehlin, D., 1987). It is known that athletes were eating fungi to run faster. In the Roman times, chariot horses used to be given a liquid which is a mix of water and honey to make them run faster. Historical records report South American natives' chewing coca buds in the past. The first doping case was seen in swimmers and cyclists during the 19th century. After modern Olympic Games started, the use of subtances among athletes started to be common and so many harmful subtances have been identified in athletes' bodies until today. http://www.tdkm. hacettepe.edu.tr

Competing and winning is as old as human history. Athletes have been trying to find food and their suitable doses to turn their bodies into powerful machines. Ancient Greek wrestlers used to eat a lot of meat to produce more muscles. Old warriors used hallucinogenic fungi to gain courage for the war (Miller, R.W. 1987). The first recorded doping use during a competition was committed by swimmers in Amsterdam in the 1860s. Doping use spread into a broader range from strychnine, caffeine to cocaine, heroine in the following years in other sports branches. Every year, the International Olympic Committee (IOC) Medicine Comission review both the list of banned or limited pharmacological substances and methods and the list of pharmacological subtances whose use is completely free or subject to special conditions. After this process, the new lists in force were issued by the Committee. Athlete's doping tests are reviewed according to the last issued list(s) and old practices in previous years are sometimes completely changed.

http://www.tdkm.hacettepe.edu.tr 01.14.2017

Today, it's not only footballers, weightlifters or marathoners using anabolic steroids. An eighteen-year-old trying to improve his/her weak body, a fifteen-year-old wanting to accelerate his/her own body growth during puberty or a person working for a job which requires sheer muscle strength... They can even use these kinds of drugs. Moreover, their use is not only limited to males. Professional or amateur female athletes, sportswomen, swimmers, body builders also use steroids to reach victory. Steroid using young individuals think that they can handle every difficult situation. These people are generally poor families' children coming from rural areas or suburbs. http://www.uoregon.edu/ iishp/Vannat.html.01. 14.2017. Their main objective is to attract attention, have success and feel better in every situation. Steroid users, especially youngsters, tend to ignore the harmful consequences of these drugs. When youngsters see their peers' muscles and height develop thanks to steroids, they want to have the same experience. They fool themselves about the effects of such subtances. Although there has not been a thorough research on this topic in Turkey, observations in sports community and things told by ordinary people show that steroid use has become common National Institute on Drug Abuse, (1989).

\section{METHODOLOGY}

Research Model: This study adopts the Collective Case Study Method from case study patterns. The data was obtained from Agri İbrahim Cecen University School of Physical Education and Sports students, and Ataturk 
University Faculy of Education Department of Physical Education and Sports Teaching students. And findings were derived with regards to descriptive analysis, percentage and frequency values.

Population-Sampling: The population of this study is composed of 200 students attending School of Physical Education and Sports at Agrı İbrahim Çecen University and 334 students attending Faculy of Education, Department of Physical Education and Sports at Atatürk University. The total number of students is 534 .

Data Collection Tool and its Application: A five point Likert inventory was administered to get students' knowledge and opinions about doping. The first part of the inventory wanted to identify demographic features, the second part was to get their knowledge and opinions. The inventory's content validity, intelligibility, and reliability was secured by Coşkun Sargın in 2006-2007 academic year and Cronbach Alpha reliability coefficient is $0,92(0,80<x<1,00$ and data collection tool is highly reliable). (Yıldırım ve Ark. 2003). It can be derived from this fact that the inventory applied to students is highly reliable.

\section{FINDINGS}

In this part of the study, Chi-square test analysis results are presented which was carried out to identify the relationship between students' demographic frequency, percentage range and their opinions about independent variables and doping use.

Table 1: Participants' Demographic Info

\begin{tabular}{|c|c|c|c|}
\hline Variable & Range & Number (N) & $\begin{array}{l}\text { Percentage } \\
(\%)\end{array}$ \\
\hline \multirow{3}{*}{ University } & Ağrı İbrahim Çeçen & 200 & 37,5 \\
\hline & Erzurum Atatürk & 334 & 62,5 \\
\hline & Total & 534 & 100,0 \\
\hline \multirow{2}{*}{ Gender } & Male & 343 & 64,2 \\
\hline & Female & 191 & 35,8 \\
\hline \multirow{2}{*}{$\begin{array}{l}\text { Is the participant doing any } \\
\text { sports? }\end{array}$} & Yes & 463 & 86,7 \\
\hline & No & 71 & 13,3 \\
\hline \multirow{3}{*}{$\begin{array}{l}\text { At what level is the } \\
\text { participant doing sports? }\end{array}$} & Competitive & 241 & 45,1 \\
\hline & Non-competitive & 222 & 41,6 \\
\hline & Not doing any sports & 71 & 13,3 \\
\hline \multirow{4}{*}{ Type of sport(s) played } & Individual & 210 & 39,3 \\
\hline & Team & 134 & 25,1 \\
\hline & Both & 119 & 22,3 \\
\hline & Not doing any sports & 71 & 13,3 \\
\hline \multirow{5}{*}{$\begin{array}{l}\text { How long has the participant } \\
\text { been doing sports? }\end{array}$} & 3 Years or above & 124 & 23,2 \\
\hline & 4-5 Years & 116 & 21,7 \\
\hline & 6-7 Years & 86 & 16,1 \\
\hline & 8 Years or above & 137 & 25,7 \\
\hline & Not doing any sports & 71 & 13,3 \\
\hline
\end{tabular}


DOĞAR et al., AJERR, 2017; 2:7

The research was carried out with 200 students from Ağrı İbrahim Çeçen University and 334 students from Erzurum Atatürk University, which makes 534 individuals in total. Students are comprised of 343 male and 191 female individuals. When we examine students' engagement with a sport(s), it is seen that $86,7 \%$ of them are doing sports and $45,6 \%$ of them are doing competitive and $41,6 \%$ of them are doing non-competitive sports.

When we examine the type of sports and the lenght of student engagement, it is seen that $39,3 \%$ of them are doing individual sports and they have been dealing with particular sport(s) for 8 years or over.

Table 2: The comparison of participants' university and their opinions about doping

\begin{tabular}{|c|c|c|c|c|c|c|}
\hline \multirow{2}{*}{$\begin{array}{l}\text { Universit } \\
\text { y }\end{array}$} & \multicolumn{6}{|c|}{ Would you say that you can try everything to be successful? } \\
\hline & $\mathbf{N} / \%$ & Yes & Partly Yes & No & Total & $\mathbf{P}$ \\
\hline \multirow[b]{2}{*}{ ì. ç. Ü. } & Number $(\mathrm{N})$ & 30 & 57 & 113 & 200 & \multirow{6}{*}{,031* } \\
\hline & $\begin{array}{c}\text { Percentage } \\
\%\end{array}$ & $15,0 \%$ & $28,5 \%$ & $56,5 \%$ & $100,0 \%$ & \\
\hline \multirow[b]{2}{*}{ A.Ü. } & Number (N) & 80 & 96 & 158 & 334 & \\
\hline & $\begin{array}{c}\text { Percentage } \\
\%\end{array}$ & $24,0 \%$ & $28,7 \%$ & $47,3 \%$ & $100,0 \%$ & \\
\hline \multirow[b]{2}{*}{ Total } & Number (N) & 110 & 153 & 271 & 534 & \\
\hline & $\begin{array}{l}\text { Percentage } \\
\quad \%\end{array}$ & $20,6 \%$ & $28,7 \%$ & $50,7 \%$ & $100,0 \%$ & \\
\hline \multirow{2}{*}{$\begin{array}{c}\text { Universit } \\
y\end{array}$} & \multicolumn{6}{|c|}{ Do you think that using doping damages the Fair Play spirit? } \\
\hline & $\mathbf{N} / \%$ & Yes & Partly Yes & No & Total & \multirow{7}{*}{, $007^{\star}$} \\
\hline \multirow[b]{2}{*}{ İ. Ç. Ü. } & Number (N) & 176 & 16 & 8 & 200 & \\
\hline & $\begin{array}{c}\text { Percentage } \\
\%\end{array}$ & $88,0 \%$ & $8,0 \%$ & $4,0 \%$ & $100,0 \%$ & \\
\hline \multirow[b]{2}{*}{ A. Ü } & Number (N) & 258 & 44 & 32 & 334 & \\
\hline & $\begin{array}{c}\text { Percentage } \\
\%\end{array}$ & $77,2 \%$ & $13,2 \%$ & $9,6 \%$ & $100,0 \%$ & \\
\hline \multirow[b]{2}{*}{ Toplam } & Number $(\mathrm{N})$ & 434 & 60 & 40 & 534 & \\
\hline & $\begin{array}{l}\text { Percentage } \\
\quad \%\end{array}$ & $81,3 \%$ & $11,2 \%$ & $7,5 \%$ & $100,0 \%$ & \\
\hline \multirow{2}{*}{$\begin{array}{c}\text { Universit } \\
y\end{array}$} & \multicolumn{6}{|c|}{$\begin{array}{l}\text { Do you think that the doping issue is known well by athletes, administrations } \\
\text { and trainers? }\end{array}$} \\
\hline & $\mathbf{N} / \%$ & Yes & Partly Yes & No & Total & \multirow{6}{*}{, $000^{*}$} \\
\hline \multirow[b]{2}{*}{ İ. ç. Ü. } & Number (N) & 20 & 98 & 82 & 200 & \\
\hline & $\begin{array}{l}\text { Percentage } \\
\quad \%\end{array}$ & $10,0 \%$ & $49,0 \%$ & $41,0 \%$ & $100,0 \%$ & \\
\hline \multirow[b]{2}{*}{ A. Ü } & Number $(\mathrm{N})$ & 65 & 179 & 90 & 334 & \\
\hline & $\begin{array}{l}\text { Percentage } \\
\quad \%\end{array}$ & $19,5 \%$ & $53,6 \%$ & $26,9 \%$ & $100,0 \%$ & \\
\hline Total & Number (N) & 85 & 277 & 172 & 534 & \\
\hline
\end{tabular}


DOĞAR et al., AJERR, 2017; 2:7

\begin{tabular}{|c|c|c|c|c|c|c|}
\hline & $\begin{array}{l}\text { Percentage } \\
\%\end{array}$ & $15,9 \%$ & $51,9 \%$ & $32,2 \%$ & $100,0 \%$ & \\
\hline \multirow{2}{*}{$\begin{array}{l}\text { Universit } \\
\text { y }\end{array}$} & \multicolumn{6}{|c|}{ Do you think that the state authority has an effective policy on anti-doping? } \\
\hline & $\mathbf{N} / \%$ & Yes & Partly Yes & No & Total & \multirow{7}{*}{, $009^{*}$} \\
\hline \multirow[b]{2}{*}{ I. Ç. Ü. } & Number $(\mathrm{N})$ & 33 & 78 & 89 & 200 & \\
\hline & $\begin{array}{l}\text { Percentage } \\
\%\end{array}$ & $16,5 \%$ & $39,0 \%$ & $44,5 \%$ & $100,0 \%$ & \\
\hline \multirow[b]{2}{*}{ A. Ü } & Number $(\mathrm{N})$ & 94 & 112 & 128 & 334 & \\
\hline & $\begin{array}{l}\text { Percentage } \\
\%\end{array}$ & $28,1 \%$ & $33,5 \%$ & $38,3 \%$ & $100,0 \%$ & \\
\hline \multirow[b]{2}{*}{ Total } & Number (N) & 127 & 190 & 217 & 534 & \\
\hline & $\begin{array}{l}\text { Percentage } \\
\%\end{array}$ & $23,8 \%$ & $35,6 \%$ & $40,6 \%$ & $100,0 \%$ & \\
\hline \multirow{2}{*}{$\begin{array}{l}\text { Universit } \\
\mathbf{y}\end{array}$} & \multicolumn{6}{|c|}{$\begin{array}{l}\text { Does your university provide information about doping during your academic } \\
\text { training? }\end{array}$} \\
\hline & $\mathbf{N} / \%$ & Yes & Partly Yes & No & Total & \multirow{7}{*}{, $000^{*}$} \\
\hline \multirow[b]{2}{*}{ İ. ç. Ü. } & Number $(\mathrm{N})$ & 34 & 63 & 103 & 200 & \\
\hline & $\begin{array}{l}\text { Percentage } \\
\%\end{array}$ & $17,0 \%$ & $31,5 \%$ & $51,5 \%$ & $100,0 \%$ & \\
\hline \multirow[b]{2}{*}{ A. Ü } & Number $(\mathrm{N})$ & 125 & 110 & 99 & 334 & \\
\hline & $\begin{array}{l}\text { Percentage } \\
\%\end{array}$ & $37,4 \%$ & $32,9 \%$ & $29,6 \%$ & $100,0 \%$ & \\
\hline \multirow[b]{2}{*}{ Total } & Number (N) & 159 & 173 & 202 & 534 & \\
\hline & $\begin{array}{l}\text { Percentage } \\
\%\end{array}$ & $29,8 \%$ & $32,4 \%$ & $37,8 \%$ & $100,0 \%$ & \\
\hline \multirow{2}{*}{$\begin{array}{l}\text { Universit } \\
\text { y }\end{array}$} & \multicolumn{6}{|c|}{ Do you think a country should continue supporting a doping using athlete? } \\
\hline & $\mathbf{N} / \%$ & Yes & Partly Yes & No & Total & \multirow{7}{*}{,009* } \\
\hline \multirow[b]{2}{*}{ ì. Ç. Ü. } & Number (N) & 47 & 45 & 108 & 200 & \\
\hline & $\begin{array}{l}\text { Percentage } \\
\%\end{array}$ & $23,5 \%$ & $22,5 \%$ & $54,0 \%$ & $100,0 \%$ & \\
\hline \multirow[b]{2}{*}{ A. $\ddot{U}$} & Number (N) & 107 & 92 & 135 & 334 & \\
\hline & $\begin{array}{c}\text { Percentage } \\
\%\end{array}$ & $32,0 \%$ & $27,5 \%$ & $40,4 \%$ & $100,0 \%$ & \\
\hline \multirow[b]{2}{*}{ Total } & Number $(\mathrm{N})$ & 154 & 137 & 243 & 534 & \\
\hline & $\begin{array}{c}\text { Percentage } \\
\%\end{array}$ & $28,8 \%$ & $25,7 \%$ & $45,5 \%$ & $100,0 \%$ & \\
\hline
\end{tabular}

The Chi-square test , which was performed to identify the relationship between students' universities and students' opinions about doping with significance level of ( $p: 0,05)$, shows that there is a statistically significant difference between student responses in Table 2 .
It is seen that "No" responses to the following items: Would you say that you can try everything to be successful? (p:,031), Do you think that the doping isse is known well by athletes, administrations and trainers? (p:,000), Does your university provide information about doping 
during your academic training? (p:,000), and Do you think a country should continue supporting a doping using athlete? (p:,009) is much higher in Ağrı İbrahim Çeçen University students than in Erzurum Atatürk University students.

"No" responses to the following item: Do you think that using doping damages the Fair Play spirit? ( $p:, 007)$ is seen to be much higher in
Erzurum Atatürk University students than in Ağrı İbrahim Çeçen University students.

"Yes" responses to the following item: Do you think that the state authority has an effective policy on anti-doping? (p:,009) is higher in Erzurum Atatürk University students than in Ağrı İbrahim Çeçen University students.

Table 3: The Relationship between Participants' Universities and Their Responses to the Item: How should a doping using athlete be fined?

\begin{tabular}{|c|c|c|c|c|c|c|}
\hline \multirow[b]{2}{*}{$\begin{array}{l}\text { Universi } \\
\text { ty }\end{array}$} & \multirow[b]{2}{*}{$\mathbf{N} / \%$} & \multicolumn{5}{|c|}{ How should a doping using athlete be fined? } \\
\hline & & $\begin{array}{l}\text { The } \\
\text { athlete } \\
\text { should } \\
\text { get a } \\
\text { lifetime } \\
\text { ban }\end{array}$ & $\begin{array}{l}\text { The athlete } \\
\text { should be } \\
\text { given 1-2 } \\
\text { year } \\
\text { suspension } \\
\text { from } \\
\text { competing }\end{array}$ & $\begin{array}{l}\text { The athlete } \\
\text { should just be } \\
\text { suspended } \\
\text { from } \\
\text { competitions } \\
\text { at the time of } \\
\text { doping use }\end{array}$ & Total & $\mathbf{p}$ \\
\hline \multirow{2}{*}{ İ. Ç. Ü. } & $\begin{array}{l}\text { Number } \\
(\mathrm{N})\end{array}$ & 60 & 119 & 21 & 200 & \multirow{6}{*}{,001* } \\
\hline & $\begin{array}{c}\text { Percenta } \\
\text { ge } \%\end{array}$ & $30,0 \%$ & $59,5 \%$ & $10,5 \%$ & $100,0 \%$ & \\
\hline \multirow{2}{*}{ Ü } & $\begin{array}{c}\text { Number } \\
\text { (N) }\end{array}$ & 142 & 143 & 49 & 334 & \\
\hline & $\begin{array}{c}\text { Percenta } \\
\text { ge } \%\end{array}$ & $42,5 \%$ & $42,8 \%$ & $14,7 \%$ & $100,0 \%$ & \\
\hline \multirow{2}{*}{ Total } & $\begin{array}{c}\text { Number } \\
(\mathrm{N})\end{array}$ & 202 & 262 & 70 & 534 & \\
\hline & $\begin{array}{c}\text { Percenta } \\
\text { ge } \%\end{array}$ & $37,8 \%$ & $49,1 \%$ & $13,1 \%$ & $100,0 \%$ & \\
\hline
\end{tabular}

The Chi-square test, which was carried out to identify the relationship between participants' universities and participants' responses to the item How should a doping using athlete be fined? with a significance level of (p:0,05), shows statistically significant difference.

The response The athlete should be given 1-2 year suspension from competing to the item How should a doping using athlete be fined? is higher in Ağrı İbrahim Çeçen university students than Erzurum Atattürk University students.

\section{DISCUSSION}

When we examine the relationship between participants' universities and students' responses to the item How should a doping using athlete be fined?, it is seen that $30 \%$ of Ağrı İbrahim Çeçen University School of Physical Education and Sports students support 
The athlete should get a lifetime ban, $59,5 \%$ of them support The athlete should be given 1-2 year suspension from competing and 10,5\% of them support The athlete should just be suspended from competitions at the time of doping use.

42,5\% of Erzurum Atatürk University Faculty of Education Department of Physical Education and Sports students support The athlete should get a lifetime ban, $42,8 \%$ of them support The athlete should be given 1-2 year suspension from competing, $14,7 \%$ of them support The athlete should just be suspended from competitions at the time of doping use. The significant difference could stem from their misunderstanding of the item.

Eröz (2007) reported $11,7 \%$ totally agree, $72,5 \%$ totally disagree and $12,5 \%$ indecisive responses from athletes to the question item: Do you have adequate knowledge about doping? Eröz, F. (2007). When we examine Ağrı İbrahim Çeçen University School of Physical Education and Sports students responses to the item Would you try everything to be successful?, it is seen that $15,0 \%$ of them say "yes", $28,5 \%$ of them say "partly yes", and $56,5 \%$ of them say "no".

When we examine Erzurum Atatürk University Faculty of Education Physical Education and Sports Teaching students' responses, we see a significant difference between them with $24,0 \%$ "Yes", 28,7\% "Partly Yes", and 47,3\% "No".

Bayram et al. (2017) reported that in their study, athletes responded "Yes" to the item Would you still use doping for the sake of being a champion even if you knew it would cause death? Bayram, M., et al. (2017).

In another study, $15,8 \%$ of the participants "Totally agreed", 55\% "Totally disagreed" and $10,8 \%$ answered "Neutral" to the item I would use doping in an international competition for my country's success. Aral, S., et al. (2006)

In our study, $10 \%$ of Ağrı İbrahim Çeçen University School of Physical Education and Sports students responded "Yes", 49\% of them responded "Partly Yes" $41 \%$ of them responded
"No" to the item Do you think that the doping issue is known well by athletes, administrations and trainers? $19,5 \%$ of Erzurum Atatürk University Department of Physical Education and Sports teaching students responded "Yes", $53,6 \%$ of them responded "Partly Yes" and $26,9 \%$ of them responded "No" to the same item. It can be inferred from the results that the higher number of "Yes" responses to the item in Erzurum Atatürk University students could be attributed to more doping coverage in their respective lectures.

Bozkurt \& et al. (2006) reported 56\% "No", $28,4 \%$ "Partly Yes" responses to the item Do you think that the doping issue is known well by athletes, administrations and trainers?

Bozkurt,N. \& et al. (2006).

$51,5 \%$ of Ağrı İbrahim Çeçen University students responded "No" to the item Does your university provide information about doping during your academic training? and $37,4 \%$ of Erzurum Atatürk University Faculty of Education Department of Physical Education and Sports Teaching students responded "Yes" to the same item justifying a more significant difference.

Yüce (1992) reported that anti-doping propaganda in Turkey and Turkish public is not adequate or very few and all 50 participants in that study agreed on the fact that there is no such anti-doping propaganda Yüce, $\mathrm{H}$. et al. (1992). Moreover, Çetinkaya et al. (2007) support our findings in another study claiming that there is no adequate training on doping issues at education institutions.

Although students with 3 years or more, 4-5 years and 6-7 years sports experience responded "Partly Yes" to a large extent to the item Do you have adequate knowledge about performance-enhancing drugs (doping)?, students with 8 years or more sporting experience responded as $43,3 \%$ "Yes" and we can infer that this significant difference may stem from the fact that students with more experience may have participated in national team competitions or they may have gotten

http://escipub.com/american-journal-of-educational-research-and-reviews/ 0008 
information about doping in national team camps.

Eröz (2007) reported that even national athletes do not have adequate knowledge about doping. Also, Öztürk et al. (2012) reported that only a few number of handball players have knowledge about doping. They claimed that this situation may sometimes cause unwanted consequences Öztürk E.G. et al. (2012).

In our study, $27 \%$ of the students who do sports competitively responded "No", \%38 of the students who do sports non-competitively responded "No" and $45,1 \%$ of students who do no sports responded "No" to the question Do you think you have adequate knowledge about beneficial and harmful drugs that athletes use? These numbers show a significant difference between "No" responses.

Çetinkaya et al. (2007) reported in their study entitled "Knowledge levels of School of Physical Education and Sports students on doping and An analysis of their attitudes" that $1,4 \%$ of students declared they have had training on doping and a majority of $98,6 \%$ declared they have had no training on doping. This result indicated that trainers who play a big role in athlete training cannot get necessary education on doping from universities Çetinkaya G., (2007).

The use of substances as doping may enhance performace for a particular competition, but these are harmful, dangerous methods that may kill an athlete and deteriorate human life in short or long term. Yalnız et al. (2004) reported that the majority of athletes did doping deliberately despite knowing the harmful effects and their continuous exposure to harmful side-effects Yalnız, I.., Gündüz, N., (2004).

When we look at the relationship between students' individual sports type and their responses to the item Do you think the method called gene doping should be classified as doping?, it is seen that $27,1 \%$ of students doing individual sports responded "Yes", 31,4\% of them responded "Partly Yes" and $31,4 \%$ of them responded "No". In team sports, the "Yes" responses are $35,1 \%$, "Partly Yes" responses are $40,3 \%$, and "No" responses are $24,6 \%$. In students that say they do both individual and team sports, there were 34,5\% "Yes" responses, $36,1 \%$ "Partly Yes" responses and 29,4\% "No" responses. In students that do no sports, there were 40,8\% "Yes", 28,2\% "Partly Yes", and $31,0 \%$ "No" responses. These figures show a significant difference.

The method known as "gene doping" is very hard to identify and we have come across a lot with it lately. Students could be educated on this method of doping widely in "Doping and Ergogenic Aids" course at tertiary level institutions.

We have seen that there has been an increase in doping cases in our country. It is said that some athletes perform doping unintentionally. Studies carried out so far have shown that knowledge levels about doping are low, so our athletes may fall into this trap.

Gençtürk et al. (2009)'s study also show that trainers and administrators have little knowledge about doping and athletes may fall into the doping trap. Trainers should be given necessary training on doping and subtances that are illegal to use. It can be said that students at physical education and sports departments and national athletes' lack of knowledge about doping could hamper the development of sports. The number of lectures on doping should be increased or seminars on doping should be given Gençtürk et al. (2009).

\section{SUGGESTIONS}

Propaganda programmes should be broadcast on mass media along with experts on doping and ergogenic aids to reach more people. These trainings should be given by specialists to prevent any promotion of doping.

Atletes, trainers and administrators should be given seminars on doping and ergogenic aids.

The meaning of sports, its aims should be continuously told and athletes should be given 
the sports culture in its fullest sense. Athletes should be given more psychological training to convince them not to use doping.

Health institutions should frequently raise consciousness among sports clubs and athletes.

International efforts to fight doping should be followed and athletes, sports scientists should be briefed on new developments \& innovations.

Trainers, sports clubs and their administrators should be given seminars on doping and ergogenic aids.

Athletes should be given seminars on athlete health, diet, and sports ethics.

The state should have an effective policy about drugs (doping). New developments in the field should be followed and athletes, sports scientists should be informed about them.

Programmes should be prepared on mass media along with experts on doping and ergogenic aids to reach more people.

Sports clubs should absolutely have active individual(s) who has(have) an education on doping.

In order to manage this, the doping concept should not be used as an "equilibrant", rather a fair and clean competition concept should be promoted and decision making process should be restructured.

\section{REFERENCES}

Açıkada C, Ergen, Spor ve Bilim.Büro-Tek Ofset Matbaacılık,Ankara 1990.

Akgün N, Egzersiz Fizyolojisi.Ege Üniversitesi Basım Evi,İzmir, 1993.

Aral, S., Brynjolfsson, E., \& Wu, D. J. (2006). Which came first, it or productivity? Virtuous cycle of investment and use in enterprise systems

Bayram M, Bayraktar,G, Tozoğlu E,, Doğar A.V. (2017) Beden Eğitimi Ve Spor Öğretmenlerinin Doping Bilgi Düzeylerinin Belirlenmesi

Bozkurt, N., Bozkurt, A. İ., Taş, E., \& Çatak, B. (2006). Denizli il merkezinde 15 yaş ve üzeri nüfusta astım prevalansı. Toraks Dergisi, 7(1), 5-10.

Çetinkaya, G., Ağyar, E., Dilbaz, K., Ö. Beden Eğitimi ve Spor Yüksekokullarındaki Öğrencilerin Doping Konusundaki Bilgi Düzeyleri ve Tutumlarının
İncelenmesi (Akdeniz Üniversitesi Örneği). 4. Akdeniz Spor Bilimleri Kongresi, Antalya, 9-11 Kasım2007.

Eröz F, Milli Düzeyde, Atletizm, Güreş, Judo ve Halter Yapan Sporcuların Doping ve Ergojenik Yardım HakkındakiGörüşlerinin ve Bilgi Düzeylerinin Belirlenmesi, Dumlupınar Üniversitesi Sosyal Bilimler Enstitüsü Beden Eğitimive Spor Anabilim Dalı Yüksek Lisans Tezi, Kütahya,2007.

Gençtürk G, Colakoglu T \& Demirel M (2009). Elit Sporcularda Doping Bilgi Düzeyinin Ölçülmesine Yönelik Bir Araştırma (Güreş Örneği). Beden Egitimi Ve Spor Bilimleri Dergisi, 3(3).

http://sIn.fi.edu/ Erişim tarihi 01.14.2017

http://www.tdkm.hacettepe.edu.tr.Erişim

tarihi

01.14 .2017

http://www.tdkm.hacettepe.edu.trErişimtarihi01.14.20

17 http://www.uoregon.edu/ iishp/Vannat.html.Erişim tarihi 01.14.2017

http://www.wada-ama.org/Erişim tarihi 01.14.2017

Kalyon T.A, Spor Hekimliği,Sporcu Sağlığı ve Spor Sakatlığı. 2. Baskı,GATA Basımevi,Ankara.1994

Kurdak S. S, Sporda Doping ve İlaç Kullanımı, Sporsal Kuram Dizisi-7, Yazarın Kendi Yayını, 1.Bası, Ankara,1996

Miller, R.W., "Athletes and Steroids: Playing a Deadly Game," FDA Consumer, November 1987.

National Institute on Drug Abuse, "anabolic Steroids: Is Bigger Better or Just Big Trouble?," NIDA Notes, Spring /Summer 1989.

Öztürk EG, Suveren S \& Çolakoğlu T (2012). Doping in Turkey, assessment of knowledge level of players about doping (handball study case). International Journal of Human Sciences, 9(1), 249-260.

Stehlin, D., "For Athletes and Dealers, Black Marcet Steroids Are Risky Business," FDA Consumer, 1987.

Temizer A, Doping Kontrolünde Gelişmeler ve Türkiye. Bilim ve Teknik Dergisi, 321, Agustos.1994.

Yalnız, İ., Gündüz, N. Ankara İlinde Vücut Geliştirme Branşında Faaliyet Gösteren Sporcuların Ergojenin Yardımcılar Konusunda Bilgi ve Uygulama Düzeyleri. Gazi Beden Eğitimi ve Spor Bilimleri Dergisi, Cilt:9, Sayı:2, Ankara, 2004, s.21-23.

Yuce, H. H., Varachi Jr, J. P., Kilmer, J. P., Kurkjian, C. R., \& Matthewson, M. J. (1992, February). Optical fiber corrosion: coating contribution to zero-stress aging. In OFC (Vol. 92,

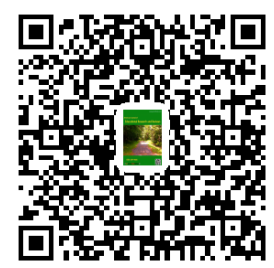

